2005-07-01

\title{
Breaking the Surface
}

\author{
Griffin, Joanna
}

http://hdl.handle.net/10026.1/16928

10.2752/174321905778054773

Cultural Politics

Duke University Press

All content in PEARL is protected by copyright law. Author manuscripts are made available in accordance with publisher policies. Please cite only the published version using the details provided on the item record or document. In the absence of an open licence (e.g. Creative Commons), permissions for further reuse of content should be sought from the publisher or author. 


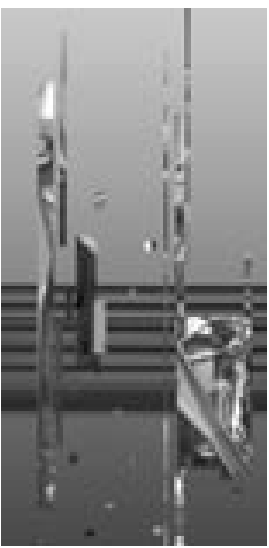

\section{FIELD REPORT}

\section{BREAKING THE SURFACE}

\section{JOANNA GRIFFIN}

JOANNA GRIFFIN IS AN ARTIST FROM THE UK WHERE SHE HAS HELD LECTURING POSTS IN FINE ART AT THE UNIVERSITY OF SOUTHAMPTON AND THE UNIVERSITY OF WOLVERHAMPTON. HER FILMS, VIDEO INSTALLATIONS, BOOK WORKS AND PRINTS HAVE BEEN EXHIBITED IN GALLERY SPACES, EVENTS AND SCREENINGS INTERNATIONALLY CURRENTLY WORKING OUTSIDE THE UK, SHE

IS PRESENTING AND DEVELOPING PROJECTS RELATING TO THE INVISIBLE ARCHITECTURE OF ORBITING SATELLITES.
ABSTRACT Research for an arts project is often as much about the experience of looking for information as the findings themselves. This article is about an investigation into the presence of submarines in British waters. The research was for a new body of work that resulted in the presentation of film, installation and interactive work at festivals, in galleries and online. In this case the fieldwork, into the inevitably political realm of nuclear submarines, led to a series of uneasy situations.

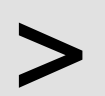

There are two locations in the British Isles where submarines harbor: the Devonport Naval Base in Plymouth, in the southwest of England, and the Clyde Naval Base at Faslane in Scotland. From these two places I watched submarines make their dignified way around Plymouth Sound or up the Firth of Clyde and likewise watched 
JOANNA GRIFFIN

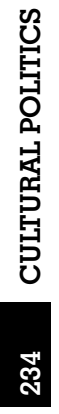

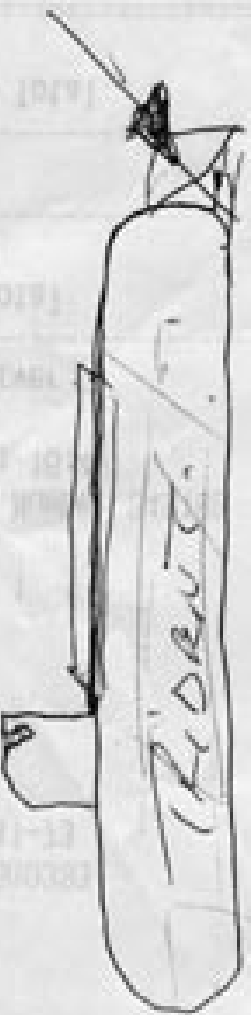


their passage out. Somewhere, away from sight of land or other boats, they submerged; their whereabouts from then on known to very few. The families of submariners only find out when the men will return by reading the daily shipping movements in the local newspaper.

This is how I tracked them; my days for a period of six months were structured by the arrivals and departures of submarines, details of which were posted in the Western Morning News. At first I was simply curious to see what a submarine looked like - whether they had that intangible eeriness in real life that I had seen in films. From the shore, with my video camera and tripod, I filmed submarines coming and going from Plymouth Sound and I waited too, early in the morning and after dark, for submarines that for one reason or another didn't appear at the times announced.

My investigation into the presence of submarines in the British Isles began as a foray into technomythology. I wanted to conjure the seabeast from the submarine, the damselfly from the helicopter. I once had a Sea King helicopter fly very low over me while I was walking alone in the English countryside. It turned out that the helicopter was preparing to land in a village school playground, as a treat for the last day of the school term, but as it flew over my head, huge and loud, it was a sublime experience, frightening but safe and without explanation. As an artist it made me rethink my practice. I began to work with the moving image as a way of translating compelling experience and exploring the creature-like presence that seemed to inhabit this colossal machine. With a video camera you can slow down the time you capture and reduce what you see to a small box in which these hitherto subdued references are revealed. Were they a subconscious creation of the engineers, these cartoon-like resemblances to creatures, a by-product of an overambitious determination to make rational killing machines, or did the designers deliberately draw on B-movie horror and science fiction to elicit irrational fear?

The submarine's mixture of associations: its creature-like design, based originally on the sperm whale, its role in covert military operations together with its much-caricatured periscope render it both terrifying and ridiculous. Central to its success as a weapon is the submarine's invisibility. The tiles that clad submarines make them resistant to sonar detection and so invisible that during the Cold War, Russian and American submarines accidentally nudged each other under the polar ice. Its draw for submariners is difficult to understand. As a "boy's toy" the submarine lacks the speed and

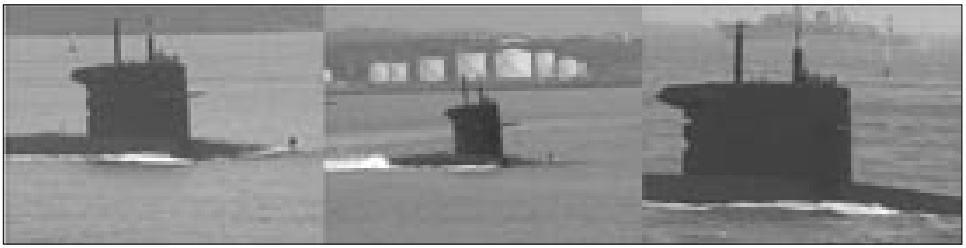




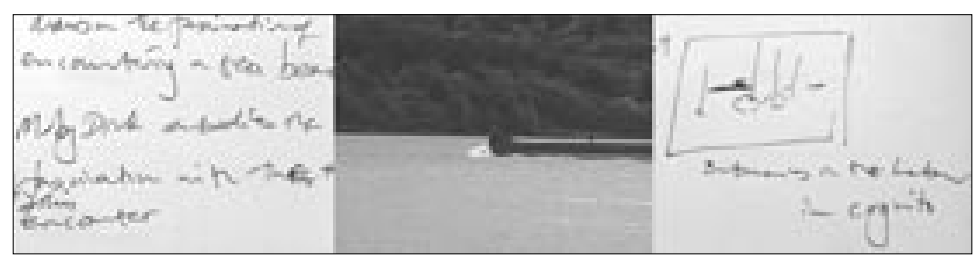

maneuverability of an airplane and there can be few craft for which the experience of the interior and exterior can be so different. The cramped and airless living quarters give no sense of being within the sea. Yet it has always been a fearful weapon with power extending beyond its technical capabilities; the black silhouette of a conning tower breaking the surface taps into a deep mythology of sea beasts and a primordial recognition of danger.

The time I have spent hunting submarines and tracking helicopters has been a quest to come closer to this strange mythology of associations within modern hard-edged technology. But it has been a nervous exploration. Being drawn to something as deeply offensive, immoral and dangerous as the dark curves of a Hunter-Killer submarine is uncomfortable. I kept going because the ambivalence of attraction and repulsion is fascinating and difficult to define. It is a kind of hovering between states of perception, at a cusp, where on one side you understand the despicableness of war machines and on the other the same machine lets you glimpse an imagined world where whale-like creatures come close into shore. It also intrigued me that I was investigating for sites of submarine activity in the Scottish lochs where the mythology of the sea beast is such a potent and discussed element of the landscape.

In the British Library I came across a book entitled An Essay on the Credibility of the Existence of the Kraken, Sea Serpent and other Sea Monsters published in 1849. It attempted to give reasoned explanations for enigmatic observations at sea such as the following:

Upon the 22nd June, in lat. $46^{\circ} 57^{\prime}$ N., long. 58 39' W., Captain Neill, of the ship "Robertson" of Greenock, then homeward bound from Montreal to Greenock, saw the head and snout of a great sea monster, of which a sketch was drawn at the time. It was first observed at about a quarter past nine A.M., on the weather-bow, about four points, and it then appeared like a large vessel lying on her beam-ends. The "Robertson" was hauled up so as to near it, and running at the rate of eight knots an hour, she, at noon, got abreast of it, distant about a mile to leeward. On observation at this time, it was discovered to be the head and snout of a great fish swimming to windward; and though an attempt was made to get closer, it could not be accomplished, because the fish, without much 
apparent exertion, kept swimming as fast as the vessel sailed. Immediately above the water its eye was seen like a large deephole. That part of the head which was above the water, measured about twelve feet, and its breadth or width twentyfive feet. The snout or trunk was about fifty feet long, and the sea occasionally rippled over one part, leaving other parts quite dry and uncovered. The colour of the part seen was green, with a light and dark shade, and the skin was ribbed. (Anon. 1849: 30)

Descriptions of sightings are inevitably compelling before a rationale is imposed that exposes the flaw or fake. They are detailed linear accounts describing something seen but not understood; potentially extraordinary until proven to be banal. For me the ambivalence holds a similar, hovering fascination, through partial knowledge and projection, to that elicited by the submarine. The glimpse of some suppressed, atavistic animal within a modern construction is part of the unsettling eeriness of submarines, and the inability to conceptualize this recognition is perhaps the basis of the terror they invoke.

At the beginning of the second attack on Iraq I went to Scotland to visit lochs used as submarine test sites. It was my second visit for this investigation. The first site was Loch Striven. It was the presumed location of a film I had seen while researching in the Imperial War Museum film archive. The words "human torpedo" had come up in the index, so naturally I was curious. A human torpedo or "chariot" was a torpedo with a kind of cockpit attached, which operated like a motorized tandem by two men in frog suits. The silent film is all smiles and laughter at the self-conscious filming process, with occasional serious attention to the new procedure being revealed for the first time to a group of reporters. I found the articles in the Colindale newspaper library, dated April 19, 1944:

Like a submarine it can navigate either on the surface at "periscope depth", the periscope in this case being the commander's head, or completely below the surface. Driven by an electric motor, it is completely silent, and it is designed for use at night, so that it is practically invisible as long as it moves slowly. (The Times 1944a: 4)

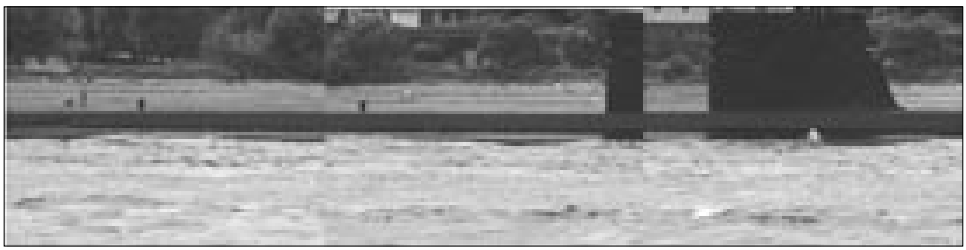


It struck me that the two men's black, helmeted heads making way just above and below the surface of the water, causing a small v-shaped wake, were a dead ringer for the Loch Ness Monster. There had to be a connection between these secret trials of bizarre inventions and the history of inexplicable sightings in the area. One take of the disjointed footage caught the two men demonstrating the torpedo out of the water chatting and laughing on the deck. Handsome in thick Aran sweaters, the older one smoking a pipe, they joked with each other and it seemed to me that this was behavior from a past generation, from an era of inspiring bravado and courage. They would have gone through terrible hardships in developing the technology: ear injuries sustained when the torpedoes hit fresh water and plummeted hundreds of feet, the coldness making their hands virtually immovable. However, here on film was the denial of uncomfortable truths British people became so famous for. Even the newspapers reported, "The woollen clothing maintains the normal circulation of the blood, and the hands remain warm even under water" (The Times 1944b: 2).

At Loch Striven I hoped to find something that would make a connection to the laughing men in the film and this time of strange underwater invention. At the opening of the loch, a grey, box-shaped pontoon floated in the middle of the water. A little further down was an equally inexplicable pier consisting of theatrical arrays of pipes. Opposite this were low wooden buildings, fenced off, and a sign "Scottish NATO Pol Depots Loch Striven Installation." The road soon stopped near a small wooden jetty with its own sign "Authorised Personnel ONLY." The typeface was slightly italic and could have dated to the 1940s, the time of the film. I walked along the water for a while, but found nothing else. On the way back I stopped at the installation. I wanted to know what this strange pier of pipes was, but I took a photo of the human torpedo men so that I could seem to be asking about that. A man in uniform came up to the fence. I asked if he thought the picture was from this loch. It could have been any loch, he said, and he could not tell me what the pier of pipes was for and there was a sign that said I could not take photos, in case I hadn't seen. Usually things go better than this. I felt he was suspicious of me; I thought he might even send a report on me to someone.

Around from Loch Striven is Holy Loch. In 1961 Harold Macmillan allowed President Eisenhower to set up a base here so that American

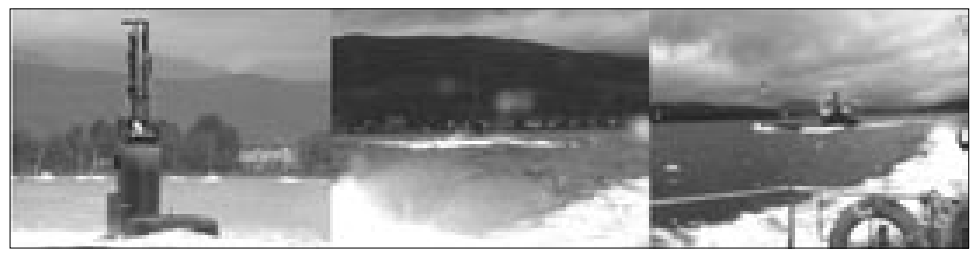


Polaris submarines could be within striking distance of the Soviet Union. Macmillan was reluctant to agree because the densely populated city of Glasgow was close by and he knew it would lose him votes, but it was the only way Britain could afford a Polaris of its own. Holy Loch is a short loch. The submarines, up to nine of them, must have filled it, together with the depot boat on which many of the American servicemen and their families lived. I looked for artifacts again. There was very little here - grey houses, industrial units for rent, all but a ghost town. I stopped at a shop and asked the man behind the counter where the base had been. He said when the base closed in 1992 most of the personnel left with the "mother boat" and the buildings associated with the base were flattened. He said he used to work there. I felt he didn't like my amazement at this - that a man working in a shop had been a part of this infamous site - but it was hard to backtrack. He said l'd struck gold with him, that most people wouldn't have known about the base and he drew me a picture of Polaris, "Poseidon" the Americans called it, with arrows pointing to the torpedo holes. He said he was still under the Official Secrets Act and that I should be careful asking questions round here; I could be picked up by plainclothes police or something.

I walked back to the car definitely worried by this. My purpose with this trip was to visit as a normal member of the public, to find out things I should be entitled to know about my country. A year before I had made my first visit to the area to go to the Faslane Naval Base. This base, just across from Holy Loch, had become the British submarine dock and after the demise of the American base it became the focus of the peace protest. Before the visit I had explained in a letter of introduction that I was an artist with a funded project and was after close-up shots of submarines. As a result, I was allowed into the base, which was protected by a fence of razor barbed wire, seven bales deep. A police launch then sped me around departing submarines so that I could get the shots I needed for my film. It was 2001, the "Centenary of the Submarine," according to the navy, and, in honor of this, eleven countries had sent submarines to Faslane for a celebration. The ones I filmed were German midget submarines, with peculiar bulbous noses and lights on the conning towers like eyes. They made extraordinary images. The ballast tanks drained out lines of white water as the bows lifted looking like prehistoric teeth. Everyone was happy to be out on the boat, and pleased I suppose to have the interest of an artist. They were philosophical about the

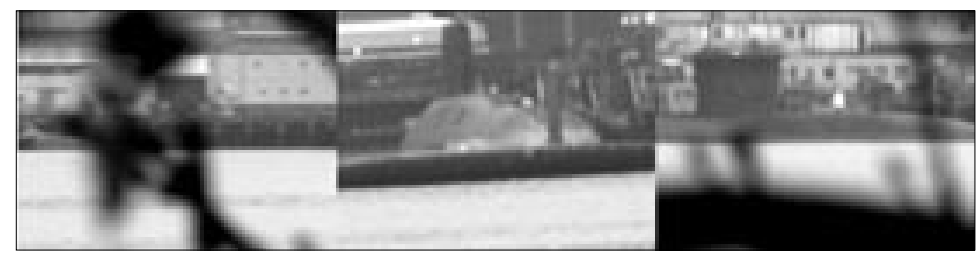


Peace Camp and accepted the fact that the two opposing ideologies inevitably coexist, unhappy in a way that they needed to be part of the navy operation in order to live in such stunning surroundings. I felt too ashamed and exhausted to visit the Peace Camp afterward. Too confused at what my agenda was in this project and how easy it was for me to talk to both sides with sympathy.

I had been on board a Hunter-Killer submarine in Devonport Naval Base at Plymouth, by means of the same ploy. They said I could contact some of the Navy press, and they were having such bad press with the nuclear reactor problem disabling the T-class submarine fleet that they could do with someone saying submarines were wonderful. I sat in the officers' quarters with the commander of HMS Talent and I asked why there were still nuclear submarines after the Cold War. It was an uncomfortable moment. The British navy was the best in the world. He asked me about my project, what did I want to do? It was a cross-examination. I would have said I was interested in the creature-like resemblances of submarines, but my real agenda had actually become deeply unclear to myself. I had just crouched in the emergency escape hatch with my tour guide and we had looked at the labeled cupboards. The one I remember was "barley sugar." He talked about the procedure that would be adopted in there, the chain of command, the need to occupy the men constantly. Then he stopped and looked down and for an imperceptible moment I could see it had struck him again this terrible possibility of being trapped. I could not criticize these people, under command, so hospitable to me, I had become too close.

At Holy Loch something equally unbearable sank in. That it was wrong to question the military's appropriation of the landscape, even that it was wrong to look. As I walked back to the car holding my till receipt with the drawing of a Trident submarine on it, I felt real dread at the enormity of the military operation and this invisible barrier to knowledge that I was beginning to mark out. Dread too at the normalizing of their procedures with uniforms, signage and gates while the peace protesters looked like the outlaws, the camp squeezed onto a small contested strip of land at the side of the road, just before the heavy barbed wire fences of the base began.

The next day I went to the Peace Camp. Soon after I arrived a police car drew up; apparently that was usual when someone new arrived. They wanted us to know they knew. I heard about the protests. People blockading the road, swimming across the loch and painting

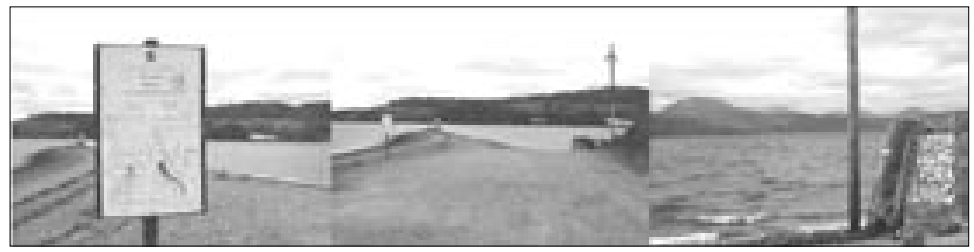


the submarines. Then they took me to some of the key sites. On the other side of the loch from the base, four of us peered through the trees, two with binoculars and two with video cameras, "monitoring" the base. Then we drove round to Coulport. This is where the weapons are kept in caves. Some indescribable statistic, my guides told me, enough bombs to destroy the world three times. I came up to a junction, noted a "keep out" sign, but nevertheless I kept driving up a road in the trees to a large closed gate. I turned the car round and we carried on back toward the camp. In no time, a Range Rover police car was in front of us and then, a minute later, in the mirror, another police car behind. I wasn't sure anyone else had noticed. Were we being escorted? Were there cameras in the trees? They stayed for a while and then turned off and again I was left with the same sense that there were boundaries here that I was being made to feel I had transgressed, while nearby the unarticulated means for inflicting genocide on the whole world were being given the respectability of uniformed protection.

On the way back to the bed-and-breakfast I stopped at Glen Douglas on Loch Long. The ship Ark Royal had been here a few weeks before, arming itself for operations in the Gulf. On breakfast television the next day I caught some of the live footage of troops entering Saddam Hussein's palace. The media spectacle located the war very far from here - this war about the illicit possession of nuclear arms.

In June 1999 three women in a leaky motorboat boarded a pontoon in Loch Goil called Maytime. It was full of computer equipment used in the process of "degaussing," the technology that renders submarines near-invisible to sonar detection. The women cut wires, threw what equipment could be moved overboard and then had a picnic while they waited to be arrested. The aim, of what became known as the "Maytime action," was to disable the Trident submarine program. The women were found not guilty on the grounds that they had been trying to prevent an even-greater crime. For a while it seemed the women's actions had forced a British court to uphold International Law and declare Britain's possession of nuclear arms to be illegal. Twelve months later, however, Sheriff Gimblett's ruling at Greenock Crown Court was challenged in a rare use of judicial power by the Lord Advocate in Scotland. As Britain had no plans to use its arms, the harboring of nuclear weapons was not a threat, and therefore not necessarily illegal. So the status quo was maintained.

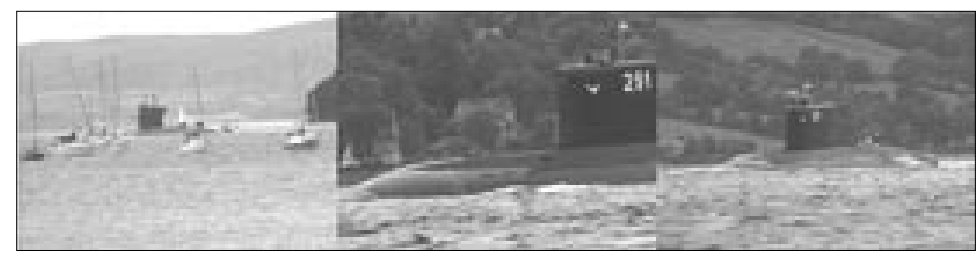




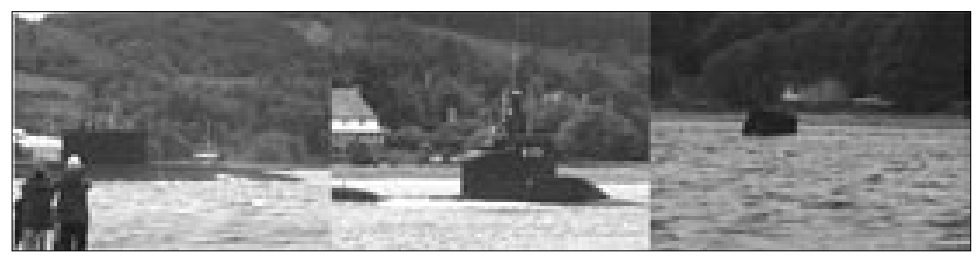

In Britain, it is usual for the image of conflict to come from afar. The unremarkable image of a submarine slowly crossing the wake of a sailboat by a seaside town is the image of war that goes unnoticed, embedded in the landscape. It was not until I went to Ireland a few months later where there was barely a plane in the sky that I realized how steeped in military architecture the British landscape is. Before I left, I walked through pine forests in mid-Wales and three times during the morning fighter jets came through the valley. They were only visible for a few seconds and the experience was strangely exciting. Yet these constant reminders of a military presence in the landscape seep into the psychology of the British people. Centuries of militarization of the landscape lead people to accept this as normal or inevitable. The presence is quiet and undefined; there does not seem to be anything there that demands a protest. Almost imperceptibly, the military becomes part of the everyday. Complicity in foreign warfare is absorbed into the surface appearance of things.

\section{ACKNOWLEDGMENT}

The research for this investigation was funded by an Arts and Humanities Research Board Small Award 2002-2003, a University of Wolverhampton Sabbatical Award 2000-2001 and a West Midlands Arts Creative Ambition Award 2000.

\section{REFERENCES}

Anon. 1849. An Essay on the Credibility of the Existence of the Kraken,

Sea Serpents and other Sea Monsters. London: William Tegg \& Co.

The Times. 1944a. "Two men astride in Diving Suits." April 19: 4. — 1944b. "Hazardous Task of Two Men." May 15: 2. 